\title{
MORE ON "DISCOUNTS" UNDER NEW YORK'S BANKING LAW: ANTIQUARIAN RESEARCH INSPIRED BY CONTEMPORARY LEGISLATION*
}

\author{
JOSEPH W. BISHOP, JR $\dagger$
}

\begin{abstract}
Practitroners and professors of corporate law have frequent occasion to observe, with varying degrees of irritation, resignation and, sometimes, amusement, that the corporation laws of a number of states resemble patchwork quilts of antique scraps-here a swatch of Uncle Eben's red flannels, there a snippet of great-grandmother's bridal gown, yonder a section of Cousin Prudence's bloomers. Perhaps an old house (usually dating from about 1840) makes a better simile, an edifice to which improvements, extensions and excrescences have been periodically added, without any attempt at basic structural change. Occasionally, one of the modern improvements blows the wiring or brings down part of the roof. The inmates promptly bawl for the legislative carpenters and repairmen, and, after a spell of furious and frequently unskilled tinkering, business life goes on more or less normally, until the next catastrophe.
\end{abstract}

These venerable and crazy structures are by no means confined to the backwoods; the corporation laws of the greatest of all commercial states, New York, constitute an outstanding example. ${ }^{1}$ A particularly instructive instance of the alarming manner in which an ancient and partially forgotten contrivance can suddenly heave and tremble, and of the dubious value of hastily improvised repair, is furnished by the history of a New York decision, Miller $v$. Discount Factors, Inc., ${ }^{2}$ and its legislative aftermath. In that case, the state's highest court, construing a statute enacted in the infancy of the Republic for the principal purpose of protecting chartered banks from competition, applied the law in such a way as to tarnish the gilt edges of several billion dollars' worth of entirely modern securities.

\section{Miller's Disease}

In February 1953, the Philip Freeman Company, a corporation engaged in the uninspiring but sometimes profitable business of jobbing plumbing supplies, felt the need of cash. Apparently because the company's credit standing would not have commended itself to a bank, Freeman turned to other, more venturesome, sources of capital. One such, located through the kindly offices

*N.Y. Sess. Laws 1958, chs. 990, 991.

†Associate Professor of Law, Yale Law School.

1. Living with the New York corporation laws has become so inconvenient and uncomfortable that the State Bar Association, alarmed by the business exodus to Delaware and other streamlined states, is vigorously urging a general revision. See, e.g., A Look at Corporation Law Revision, 29 N.Y.S.B. BuLL. 71 (1957).

2. 1 N.Y.2d 275,135 N.E.2d 33, 152 N.Y.S.2d 273 (1956). 
of a note broker, was Discount Factors, Inc., a New York stock corporation. Although Discount did not pretend to the dignity of a bank, it habitually stepped in where bankers feared to tread; its business was somewhat euphemistically described by the Appellate Division of the New York Supreme Court as "the granting of financial assistance to merchants by lending money and taking back notes or buying their paper"3-for a price. In substance, Discount lent $\$ 14,325$ to the Freeman Company and received as evidence thereof five promissory notes of the latter, payable one per month for five months. The principal amount of each was $\$ 3,000$, each bore six per cent interest, and each was endorsed by Miller, the brother-in-law of the borrower's president." It will immediately be apparent to the arithmetically minded reader that Discount's compensation equalled the swingeing rate of twenty-four per cent per annum, or would have if Discount could have collected it.s

The transfusion failed: Freeman Company languished and languishing did die. The endorser, Miller, having paid the first three notes to mature and evidently wearying of paying for oats consumed by a dead horse, took counsel to discover whether, somewhere in the laws of New York, there might not be a way out of his distasteful predicament. The upshot was that he refused to pay notes four and five on the ground that they had been discounted in violation of section 131 of the Banking Law, which barred corporations that were not banks from "making discounts," and were therefore void." Worse, he

3. Miller v. Discount Factors, Inc., 285 App. Div. 772, 777, 141 N.Y.S.2d 140, 144-45 (1.955), modified, 1 N.Y.2d 275, 135 N.E.2d 33, 152 N.Y.S.2d 273 (1956).

4. Actually, the Freeman Company received only $\$ 13,825$ in cash. Discount withheld $\$ 675$, variously described as a "discount charge," "premium" and "bonus charge," and paid an additional $\$ 500$ to the note broker. Miller v. Discount Factors, Inc., 285 App. Div. 772, 774, 141 N.Y.S.2d 140, 141-42 (1955). Since the latter payment discharged an obligation of Freeman Company, that corporation may be said to have received $\$ 14,325$.

5. Usury was not an issue in the case, since the maker of the notes was a corporation; in New York, a corporation cannot defend on the ground of usury. N.Y. GEN. Bus. LAw \$ 374. Nevertheless, had it not been for the pervasive odor of usury about the transaction, it is conceivable that the court of appeals might not have applied the law to Discount with such savage literalness.

6. Prior to April 25, 1958, that section provided in pertinent part that:

No corporation, domestic or foreign, other than a national bank or a federal reserve bank, unless expressly authorized by the laws of this state, shall employ any part of its property, or be in any way interested in any fund which shall be employed for the purpose of receiving deposits, making discounts, receiving for transmission or transmitting money in any manner whatsoever, or issuing notes or other evidences of debt to be loaned or put into circulation as money. All notes and other securities for the payment of any money or the delivery of any property, made or given ... to secure the payment of any money loaned or discounted by any corporation or its officers, contrary to the provisions of this section shall be void.

Any argument that an ordinary business corporation might be authorized by law to make discounts was foreclosed by the complementary provision of $\$ 18$ of the General Corporation Law, which stated inter alia that:

No corporation, domestic or foreign, other than a corporation formed under or subject to the banking laws of this state or of the United States, and except as 
brought suit to recover what he had paid on notes one, two and three, on the ground that payment had been made under a mistake of law. ${ }^{7}$

The trial court sustained Miller's defense as to notes four and five, but an unsympathetic jury found that he had paid one, two and three voluntarily and with knowledge of his rights. On appeal, he fared still worse, for the appellate division reasoned that, since no "interest," eo nomine, but only a "bonus," had been deducted in advance, it was questionable whether the transaction was a discount at all. Moreover, the rate would have been illegal if charged by a bank. "It is the combination of circumstances here, the loan being beyond that possible by a bank, and the fact that there was no deduction of interest in advance, which takes the transaction out of the realm of encroachment on a bank's business and removes the prohibition of the statute."9

Such reasoning invited reversal. It got it. The New York Court of Appeals conceived the question before it in the simplest terms: "whether under the facts in this case the instant transaction . . . avoids the prohibition of section 131 of the Banking Law, because only a so-called bonus charge, and not the interest provided for on the face of the notes, was deducted when the loan was made." 10 So stated, the question practically answered itself. Five of the seven judges had no trouble whatsoever in finding that the "bonus charges" were actually a part of the compensation for the loan and therefore constituted interest; therefore, their deduction in advance was the making of a discount; therefore, the notes were invalid. Q.E.D. The majority made equally short work of the more ingenious but still unappealing idea that the way to take a discount out of the scope of section 131 was to charge a rate of interest that would have been usurious if levied by a bank. The court reversed the appellate division as to notes four and five and affirmed it as to one, two and three"not, however, upon the ground that the notes in question were valid."11

I do not wholly share the outraged reaction of many commentators to the Millor case; I happen to think, for reasons which will appear, that on its facts the result in that case is defensible. To be sure, the Banking Law's arbitrary distinction between deducting interest in advance and collecting it as it is earned

therein provided shall by any implication or construction be deemed to possess the power of carrying on the business of discounting bills, notes or other evidences of debt, of receiving deposits, of buying and selling bills of exchange, or of issuing bills, notes or other evidence of debt for circulation as money, or of engaging in any other form of banking ....

7. N.Y. Civ. PrAC. ACT \$ 112-f.

8. As a general rule, under penalty of forfeiting the entire interest, a New York bank may not charge more than $6 \%$ per annum on a loan. N.Y. Banking LAw $\S 108$. The $6 \%$ may be deducted in advance, which, of course, effectively increases the rate, depending on the schedule for repayment of the principal. But no arithmetical legerdemain could raise legal bank interest to any such height as $24 \%$.

9. Miller v. Discount Factors, Inc., 285 App. Div. 772, 777-78, 141 N.Y.S.2d 140, 145 (1955).

10. 1 N.Y.2d at 279,135 N.E.2d at 36,152 N.Y.S.2d at 277.

11. Id. at 283,135 N.E.2d at 39,152 N.Y.S.2d at 280 . The dissenters wrote no opinion. 
is economic nonsense. ${ }^{12}$ But that is the fault of the legislature, not the court. On its face, without consideration of its history or prior construction, section 131 certainly forbade the making of discounts by corporations other than banks; equally clearly, it voided "all notes and other securities . . . made or given to secure the payment of any money ... discounted by any corporation . . . contrary to the provisions of this section." According to the common understanding of courts, lawyers, bankers and businessmen, the word "discounting" precisely describes the lending of money with interest deducted in advance. ${ }^{13}$ It is not easy (although it is far from impossible) for a court to conjure away the plain English meaning of statutory language. ${ }^{14}$ In the second place, even if the statute were construed less mechanically, with more effort to find what the legislature actually intended, it could plausibly be argued that the facts of the Miller case really did present the sort of evil intended to be scotched: Discount Factors was engaged solely in a business which might be described as "banking" and had made a number of loans like those to the Freeman Company. ${ }^{15}$ If the court of appeals had carefully confined its decision to the facts before it, or had simply reversed per curiam, the financial world would have little noted nor long remembered what it said. Instead, the majority employed reasoning, and clothed that reasoning in language (with plenty of italics for emphasis), which impelled a nearly contemporary commentator to compare the case to the explosion "in thickly populated financial circles [of] a time bomb."16 The perturbation in the vicinity of Wall and Broad Streets,

12. See Kripke, Illegal "Discounts" by Non-Banking Corporations in New York, 56 Colum. L. Rev. 1183, 1190-95 (1956).

13. See, e.g., Evans v. National Bank, 251 U.S. 108, 113 (1919); National Eank v. Johnson, 104 U.S. 271, 276 (1881) ; Fleckner v. Bank of the United States, 21 U.S. (8 Wheat.) 338, 350 (1823) ; Philadelphia Loan Co. v. Towner, 13 Conn. 249, 259-60 (1839); Atlantic State Bank v. Savery, 82 N.Y. 291, 302 (1880) ; City Bank v. Bruce, 17 N.Y. 507, 515 (1858). A century ago, indeed, the deduction of interest in advance seems to have been so much the normal method of lending money that the terms "loan" and "discount" were used more or less interchangeably. See People v. Bartow, 6 Cow. 290, 294 (N.Y. Sup. Ct. 1826) ("The discounting of notes is, undoubtedly, the principal business of a banking institution."); cf. 1840 N.Y. BANK COMM'RS ANN. REP. 5, 13; 1841 N.Y. BANK Comm'rs Ann. Rep. 10-12; Report of the Committee on Banking and Insurance Companies 8 (N.Y. Sen. Doc. No. 27, 1835). Prior to the Miller case, in fact, some of the inferior courts of New York seemed to see little difference between loans and discounts for the purposes of $\S 131$. Cf. Proper Spirit Trading Corp. v. Schilowitz, 140 Misc. 171, 172, 250 N.Y. Supp. 118, 120 (App. T. 1931) ; Voluntary Ass'n, Inc. v. Goodman, 137 Mise. 388, 390, 244 N.Y. Supp. 328, 330-31. (N.Y.C. Munic. Ct. 1930).

14. See, e.g., Browder v. United States, 312 U.S. 335, 338 (1941).

15. See note 58 infra and accompanying text.

16. Kripke, supra note 12 , at 1183 . The author added, however, that the explosion was likely to cause more nuisance than real injury. Ibid. Elsewhere the decision was said to have "staggered the financial and commercial mechanism." Kupfer, Prohibited Discounts Under the Banking and General Corporation Laws: The Impact of Miller v. Discount Factors, Inc., 12 Record of N.Y.C.B.A. 30 (1957) ; see New York Credit Men's Adjustment Bureau, Inc. v. Samuel Breiter \& Co., 253 F.2d 675, 676 (2d Cir. 1958). 
in the city, county and state of New York, can best be understood in the light of some representative excerpts from the opinion:

The pertinent statutes . . . plainly forbid all discounts. In this case Discount ... used its funds and deducted in advance the larger part of its compensation. ... This was the exercise of a banking power prohibited by section 18 of the General Corporation Law, and, no matter what the sum deducted is called, and no matter what the percentage retained, it was the making of a discount which is invalidated by section 131 of the Banking Law.

.... The authorization to lend money in said section 18 [of the Stock Corporation Law ${ }^{17}$ ] does not entitle a domestic corporation, not organized under the Banking Law, to discount negotiable paper. . . . [I]t is the lending of money, and the deduction of the compensation for the loan in advance, from notes given to secure repayment thereof, that is prohibited by section 131 of the Banking Law. . . . Discount could have made a loan and charged any rate of interest that was agreed upon, but if the loan is evidenced by promissory notes, and the charges therefor are deducted in advance, in whole or in part, it transgresses the Banking Law.

It is also no answer to urge that even if there were a discount of interest, the notes are still valid because Discount was not carrying on any other banking operations, but was merely exercising a single power also exercised by banks of discount. The prohibitions of both section 18 of the General Corporation Law and section 131 of the Banking Law are phrased in the disjunctive, and no corporation may be deemed to possess the power to discount notes or do any of the other acts prohibited by said statutes. If such corporation does make discounts, all notes so discounted are void, Banking Law, § 131.

.... [T] hese five notes were discounted in contravention of section 131 of the Banking Law and are therefore void. ${ }^{18}$

This language obviously made painful reading for "commercial finance companies" of Discount Factors' ilk. Even had the opinion been explicitly limited to such lenders, it would still have created some stir, for these entrepreneurs play a considerable role in the financing of that populous class of corporations whose paper is not attractive to conservative lenders. ${ }^{19}$ But few of the acute and well-feed gentlemen who cluster at the lower end of Manhattan Island would have lost much sleep over the troubles of Discount Factors or its congeners. What caused the expenditure of a good many thousand hours of very expensive legal time was the ease with which the court's language could be applied to transactions commonly engaged in by large, conventional and reputable suppliers of capital. For example:

17. "Any stock corporation ... may purchase, [or] acquire ... bonds, notes . . . of any person ... or corporation ... if authorized in its certificate of incorporation. . .."

18. 1 N.Y.2d at $281-83,135$ N.E.2d at $37-38,152$ N.Y.S.2d at $279-80$.

19. See Guthamann \& Dougald, Corporate Financtal Policy 445-50 (3d ed. 1955). Some of the transactions of Discount Factors' bigger brothers involve sums which are by no means contemptible. See, e.g., Bellanca Corp., SEC Exchange Act Release No. 5706 (June 2, 1958). Bellanca borrowed $\$ 3,976,090$ from The Mastan Company, described by the Commission as "a commercial financing firm," for which it gave its ten-month note, bearing interest at $6 \%$, in the principal amount of $\$ 4,476,190$. 
- Corporations frequently try to gain face by making their bonds, debentures or other evidences of indebtedness bear a lower interest rate than can be justified by the corporation's credit. Payment of the remainder of the proper interest rate is superficially concealed by issuing the bonds for less than parthat is, at a discount. ${ }^{20}$ Many such issues have been placed with insurance companies and other institutional lenders.

- Part of a corporate underwriter's spread in the issue of new debt securities may be attributable to its purchase of the securities for less than par. $^{21}$

Corporations of high credit often obtain short-term funds by issuing their notes at a discount, sometimes through a commercial paper broker, who resells to banks or other investors; sometimes directly to investors, who may themselves be corporations. ${ }^{22}$

Since New York is the financial capital of the nation, a very high percentage of the foregoing transactions take place there and involve corporations incorporated or doing business there. It did not take much imagination to see that each of these common types of financing might be described as lending money and taking all or a part of the compensation in advance, and therefore as a discount in violation of the Banking Law, so that the notes, bonds, debentures or other instruments evidencing indebtedness so discounted might be void; in fact, the less the imagination employed, the easier the operation. It might be "inconceivable" that the court of appeals could "reach so fantastic a result" as the invalidation of such instruments, ${ }^{23}$ and it might also be true that "antiquarian research" would show that the statute had no proper application to such transactions, ${ }^{24}$ but large moneyed institutions and their counsel are notoriously allergic to doubt. There is an axiom of corporate finance to the effect that nothing is so timid as a million dollars; in this case a good many billions were involved. Obviously, the quick, clean and easy method of exorcising the doubt was to amend the statute, and that without niggling delay. No time was lost. It was too late to do anything in 1956, the court of appeals having been so inconsiderate as to hand down its decision after the legislature had adjourned, but a frontal assault on the 1957 legislature produced rapid, if disconcerting, results. The Assembly and the Senate passed bills ${ }^{25}$ which would have deftly amended sections 18 of the General Corporation Law and 131 of the Banking Law by adding to each the proviso that,

20. See 1 Dewing, Financial Policy of Corporations 647-50 (5th ed. 1953). Sometimes an issue is sold at less than par because the issuer has miscalculated the receptivity of the market.

21. 2 id. at $1056-57,1089-90$.

22. See Guthmann \& Dougall, Corporate Financtal Policy $442-45$ (3d ed. 1955); Kripke, supra note 12 , at $1185,1195$.

23. Id. at 1185 .

24. Id. at 1186 .

25. N.Y. Assembly Introductory No. 4045, Printing No. 4795, entitled "AN ACr to amend the banking law, in relation to the prohibition on encroachment upon certain powers of banks and trust companies"; A.I. 4037, Pr. 4297, entitled "AN Acr to amend the general corporation law, in relation to the prohibition of the exercise of banking powers." 
The purchase or other acquisition on original issue or subsequent transfer for less than the principal amount thereof or otherwise at a discount of any evidences of indebtedness or other obligations for the payment of money heretofore or hereafter issued shall not by reason of such discount be or be deemed to have been a violation of the provisions of this section.

The Governor vetoed them. ${ }^{26}$

The grounds of the veto require, though they may not repay, close study. After pointing out, correctly, that the bills were "evidentally [sic] intended to remove any doubts as to the validity of some of the transactions to which the [Miller] decision may be held to apply," Governor Harriman noted that the amendments might "unduly remove safeguards which the law provides in connection with practices that are considered as traditional banking activities." Specifically, "the retroactive provision of the bill which makes it applicable to transactions involving obligations for the payment of money 'heretofore or hereafter issued' . . . raises a serious question, in that it would validate transactions declared by the Court of Appeals to have been illegal when they were consummated."27 Finally, and with some justification, he denounced as a "travesty" the legislative practice of rushing important bills through the last days of a session," and remanded the amendments for "further study and ... public hearings at which they may be thoroughly discussed and debated, with ample opportunity afforded to groups representing banks, factors, other types of discount companies and the public at large."

Gubernatorial vetoes are not the end of matters which agitate insurance companies. At the 1958 session, the legislature again passed amendments. There is room for doubt as to the amount of study and thorough public discussion they received. Since the amending bills constituted chapters 990 and 991 (out of a total of 992) of the Laws of 1958, it may be conjectured that the legislature was not much more deliberate that year than it had been the year before. If the Governor regarded their enactment as a travesty, he kept it to himself, for he signed the bills. But at least it was clear that some attention had been paid to his veto message, inasmuch as the language of 1957 had been altered in two significant respects. In the first place, the words "heretofore or hereafter issued" had vanished. ${ }^{29}$ By way of compensation, the legislature eliminated the old statutory penalty - that is, it removed from section 131 the sentence which explicitly made void all notes or other instruments given to secure the payment of money that were discounted by a corporation

26. Memorandum filed with the bills cited in the foregoing footnote, N.Y. Legis. Serv. Release, April 27, 1957.

27. It is not clear why there should be serious objection to this obvious purpose of the bills. Possibly the Governor thought that if it is unconstitutional to impair the obligation of a valid contract, the converse should be equally true-i.e., that the state cannot impair the invalidity of an unenforceable contract.

28. One bill was passed on March 25, 1957, the other on March 30,1957, which was the last day of the session.

29. Similarly, the words "be or be deemed to have been" were changed to "be or be deemed to be." 
contrary to the provisions of the statute. ${ }^{30}$ There is no longer, then, a specific penalty for violation of the statute; and that vacancy, as we shall see, may pose the courts certain peculiar dialectic difficulties.

Certainly these obscure and fragmentary annals are far removed from the sort of detailed and voluminous legislative history into which the supreme Court of the United States likes to sink its teeth. Nevertheless (deferring for the moment the effect of deleting the statutory penalty), it is tolerably plain that the New York legislature intended (if, pace the Governor, it had any conscious intent at all) to leave with all their original infirmities evidences of debt discounted prior to the date of approval of the bills. Indeed, they may be rather more infirm than before, for now it can be argued that the legislature has evidenced its endorsement of the Miller case by its solicitude not to "validate transactions declared by the Court of Appeals to have been illegal when they were consummated." And there's the rub. The securities thus left unhealed by the sovereign's cleansing touch prima facie include every outstanding evidence of indebtedness which was discounted in New York by an insurance company, underwriter or other nonbanking corporation prior to April 25, 1958. For them, the Miller case is still law-and, of course, some of these obligations have very long maturities.

Moreover, the fears inspired by that case may be something more than bogeymen conjured up by lawyers to frighten nervous clients. Needless to say, it is in the last degree unlikely that the kind of corporation which can place a debt issue with a group of insurance companies or float it through a reputable underwriter would make a crude attempt to welsh on its obligations on the strength of the Miller case; sanctions at least as strong as any known to the law stand in the way of such an effort to turn a dishonest dollar. But it is not hard to imagine contexts in which the affliction of securities with what may be termed Miller's Disease might work real mischief to the interests of the holders thereof. Suppose, for example, that the issuing corporation becomes insolvent: no captious ethical considerations are likely to inhibit other classes of creditors from taking the fullest advantage of any weakness created by the Miller doctrine; and the infirmity, if not fatal, might very well be employed to justify a plan of reorganization much less favorable to the holders of the discounted securities than the one which would have been required had their validity been incontestable. ${ }^{31}$ Suppose, again, for another example, that the issuing corpora-

30. See note 6 supra.

31. Cf. In re Associated Gas \& Elec. Co., 61 F. Supp. 11 (S.D.N.Y. 1944), aff'd, 149 F.2d 996 (2d Cir. 1945). Corporation $A$ had outstanding some $\$ 265,000,000$ of debentures whose indentures provided, inter alia, that $A$ would not transfer its assets as an entirety if that would impair the rights of the debenture holders. $A$ thereupon transferred virtually all of its assets to its subsidiary, $B$, in exchange for demand notes of $B$, which, in turn, by a mysterious and disputed process, were transmuted into "collapsible" obligations of $B$-i.e., obligations convertible into common stock at $B$ 's option. Howard Hopson, the presiding thaumaturgist at this changing of wine into water, thereupon persuaded a substantial number of $A$ 's debenture holders to exchange their debentures for either a lesser quantity of $B^{\prime}$ s debentures or an equal quantity of lesser quality. The construction, validity 
tion, as issuing corporations often do, finds burdensome some of the protective covenants-e.g., a restriction on dividends or investments-in the instrument under which discounted securities have been issued. Though it may have no intention of repudiating its debt, or even of overtly breaching its covenants, the issuer's arguments as to the construction or applicability of those covenants would assuredly be made more effective by the possibility that, in the last analysis, the covenants simply are nullities and compliance with them an act of grace.

Such possibilities as these, however unpalatable, cannot safely be ignored. Unless the legislature returns to the subject, which is improbable, the conclusion seems inescapable that the expenditure of time on research, antiquarian and otherwise, for the purpose of ascertaining with some precision the impact of the Miller case, will not be unprofitable.

The object of the exercise should be to furnish to future courts reasons, better than those employed by the appellate division in Miller, for refusing to apply to modern financial transactions an obsolete statute which the legislature has elected not to kill but to leave in a sort of half life. The strongest argument against extension of the Miller doctrine to discounting by institutional investors or underwriters is also the simplest: in the light of the history of the statute, and the cases construing it prior to the Miller case, a court should have no difficulty in finding that it was never intended to be applied to the making of discounts by a nonbanking corporation as an incident to the conduct of some other business.

\section{Enter The Antiquarian}

The history of the statute is long and in places obscure, but parts of it are well known and can be summarized briefly. Prior to 1838, New York granted charters to banking corporations only by special act of the legislature, and granted but few of those. ${ }^{32}$ In part, the legislative purpose was the laudable one of controlling the flow of bank notes circulating as currency, in part the not so laudable one of reserving the lucrative privilege of banking for those who had established some claim to legislative favor. ${ }^{33}$ As might have been

and enforceability of such protective covenants were then (and are now) very dubious. Comment, 46 Y ALE L.J. 97 (1936). But the courts held that the possibility that $A$ 's debenture holders might prevail in litigation based on an alleged breach of their covenants was sufficient to make fair and equitable a compromise plan of reorganization which put the $A$ and $B$ debenture holders on a parity with respect to $B$ 's assets.

32. The first bank chartered by the state was the Bank of North America, intended to be a central bank like the Bank of England: N.Y. Sess. Laws 1782, ch. 35 (5th Sess.). The act provided that "no other bank, public or private, shall be established within this State during the present war with Great Britain," and in fact no state bank was incorporated until chapter 37 of the Laws of 1791 created the Bank of New York. Consolidator's Notes-Banking Law of 1909, N.Y. Banking LAw pt. I, at 2-3.

33. "The object of these enactments [i.e., the progenitors of $\S 131$ of the Banking Law] ... was to protect the chartered banks in the monopoly of banking, and to exclude other corporations, associations or individuals from conducting a banking business in 
expected, mere denial of legislative charters to those who could neither seduce nor hoodwink ${ }^{34}$ the legislature proved too weak a fence to keep the pigs out of the clover. At least as early as 1803 , groups of enterprising citizens were growing fat in the banking business without benefit of legislative grants. The first restraining act, the not very remote ancestor of section 131 of the Banking Law, was passed in 1804.35 As learned contemporary counsel said in argument a few years later, "The intention of the [restraining] act is to be discovered from the cause of making it. In 1803, certain associations were formed in the City of $N e z-Y$ ork, to carry on banking business, without any charter of incorporation for that purpose; and this act was passed in 1804."30 The Act of 1804 provided in substance that "no person unauthorized by law shall subscribe to or become a member of an association, institution or company, or proprietor of any bank, or fund for the purpose of issuing notes, receiving deposits, making discounts, or transacting any other business which incorporated banks may do or transact by virtue of their respective acts of incorporation." All notes and other securities given to such an unauthorized company were declared to be void. Apparently the chartered banks still felt their monopoly insufficiently protected, for in 1818 the act was supplemented by another which made it unlawful for individuals, as well as associations and corporations, to "keep any office of deposit for the purpose of discounting promissory notes, or for carrying on any kind of banking business or operations, which incorporated banks are authorized by law to carry on." or to issue bills or notes as private bankers, unless expressly authorized by law. A forfeiture of $\$ 1,000$ was decreed for every violation of the statute, but evidences of debt which contravened it were not made void. ${ }^{37}$ In 1829, the Acts of 1804 and 1818 were re-enacted, without significant changes in wording, as part of the Revised Statutes. At the same time, the legislature, still anxious to plug any breaches in the wall surrounding its chartered monopolies, added a provision - substantially identical to the second sentence of the present section 131(1) of the Banking Law-to the effect that "no incorporated company, without being authorized by law, shall employ any part of its effects, or be in any way interested in any fund that shall be employed, for the purpose of receiving

either department, of issue, deposit or discount." Pratt v. Short, 79 N.Y. 437, 447 (1880). Elsewhere the court referred to "the policy upon which the restraining acts were passed, viz.: the securing of the monopoly to special favorites of the Legislature . . ." Id. at 448. See also Savage, $J$., concurring in New-York Firemen Ins. Co. v. Ely, 2 Cow. 678, 711 (N.Y. Sup. Ct. 1824).

34. See note 45 infra.

35. N.Y. Sess. Laws 1804 , ch. 117 , re-enacted without change by N.Y. Sess. Laws 1813 , ch. 71.

36. Nathan Williams, arguendo, in Utica Ins. Co. v. Scott, 19 Johns. R. 1, 3-4 (N.Y. Sup. Ct. 1821). The legislature of 1804, like the legislatures of 1957 and 1958 , seems to have reacted to the plaintive cries of large moneyed corporations with the alacrity of a tigress protecting her cubs.

37. N.Y. Sess. Laws 1818, ch. 236. See People v. Bartow, 6 Cow. 290, 293-94 (N.Y. Sup. Ct. 1826). 
deposits, making discounts or issuing notes or other evidences of debt, to be loaned or put into circulation as money." 38

By 1837, a new wind was blowing. The pampered darling of the legislature, the bank monopoly, had become "intensely odious." 39 In that year, the business of banking (except for the issuance of circulating notes) was in effect thrown open to everyone except corporations by the repeal of so much of the 1829 act as prevented "a person or association of persons not incorporated, from keeping offices for the purpose of receiving deposits, or discounting notes or bills." 40 For the next hundred and twenty years the legislature made no change in the restraining act that seems germane to the present inquiry. ${ }^{41}$

Thus, after 1837, section 3 of the 1829 act, applicable only to corporations, became the solitary restriction on making discounts-and in the next year there was enacted a general law for the incorporation of banks. If the restraining act had a purpose any longer, it was only that of "restraining corporations from exercising powers not granted by their charters" 42 -more exactly stated, of compelling people who wanted to do a banking business in corporate form to incorporate themselves as banks and subject themselves to regulation as banks. That policy was supported by what is now section 18 of the General Corporation Law, which provides, in essence, that no corporation not formed under the Banking Law "shall by any implication or construction be deemed to possess the power of carrying on the business of discounting bills, notes or other evidences of debt, of receiving deposits, of buying and selling bills of exchange, or of issuing bills, notes or other evidences of debt for circulation as money, or of engaging in any other form of banking . . ."43

38. N.Y. Rev. Stat. 1829 , pt. I, ch. 20 , tit. $20, \S 3$.

39. See Curtis v. Leavitt, 15 N.Y. 9, 77 (1857). The decision, which runs to 289 pages, reviews exhaustively, and somewhat exhaustingly, the history of New York banking legislation from the earliest times down to its own day.

40. N.Y. Sess. Laws 1837, ch. 20.

41. The repeal act of 1837, note 40 supra, left an apparent anomaly: while it was now lawful for an individual or unincorporated association to keep an office for the purpose of receiving deposits or discounting notes, there was still a heavy fine for subscribing to or becoming a member of such an association, or being "interested" in any bank or fund created for any such purposes. In 1852 the editors of the Fourth Edition of the Revised Statutes, Messrs. Denio and Tracy, apparently without any legislative warrant whatsoever, recast the 1829 act, as amended by that of 1837 , into substantially the form in which subsections 1 and 2 of $\S 131$ existed immediately prior to the 1958 amendment. They took considerable liberties with the text of the statute, presumably in order to express what they took to have been the intent of the legislature of 1837 and to eliminate the anomaly mentioned above. Not until 1882 did the legislature ratify their version-though it was certainly treated as law during the intervening thirty years-by enacting it as part of the new consolidated banking law. N.Y. Sess. Laws 1882, ch. 409. This is the sort of diffculty which may have deterred lawyers and judges from engaging in the antiquarian research which might have averted the great Miller panic.

42. Pratt v. Short, 79 N.Y. 437, 448 (1880).

43. Section 18 traces its descent to Part I, Chapter 18 , Title $3, \S 4$ of the Revised Statutes of 1829. It underwent no significant change until 1892, when the phrase "the power of discounting bills" was changed to "the power of carrying on the business of dis- 
This modest policy certainly does not require that nonbanking corporations be prohibited from discounting evidences of debt as an incident to the conduct of some business other than banking-especially a business like that of underwriting or insuring, which is itself heavily regulated. Moreover, there is good legislative evidence that so sweeping a prohibition was not regarded as necessary even to the original purpose of protecting chartered monopolies, and that. if the legislature of 1804 loved the banks which it had created, it also had a healthy respect for the rich and powerful merchants of New York City and a corresponding reluctance to disrupt the ordinary operations of their counting houses. That evidence, indeed, has long been deeply buried in obscurity; it seems to have been wholly unknown to court and counsel in the Miller case. But antiquarian research reveals that on April 10,1804, the day before the original restraining act became effective, the legislature passed an interpretative act, evidently intended to dispel much the same sort of alarm as that which again struck the financial community a century and a half later. It is worth quoting in full:

Whereas the chamber of commerce of the city of New York have, by their respectful memorial to the legislature, expressed apprehension that the bill passed both houses of the legislature at the present session, entitled 'an act to restrain unincorporated banking associations' may be so construed as to subject individuals to inconvenient restrictions in their usual commercial business and pursuits. Therefore, for the removal of these apprehensions,

$B e$ it enacted and declared, that nothing in the said bill contained, shall be deemed or construed to prevent any person, association or company, from transacting or pursuing any business other than such as companies or banks, incorporated for the express purpose of banking, usually do or transact, nor shall anything in the said act contained, be deemed or construed in any manner or way to affect the incorporation in the city of New York created by virtue of an act, entitled 'An act for supplying the city of New York with pure and wholesome water'.44

Having passed this exceedingly interesting bill, the legislature proceeded to bury it under the wrong headstone; it appears in the Session Laws of 1804 as section IX of a chapter entitled "An act to incorporate the Columbian Friendly Union Society in the City and County of Albany"-which helps to account for the fact that it seems to have been disinterred by a court only once since 1804 and not at all since 1832 . There is certainly a fishy odor about the episode, the reason for which, even at this distance in time, may not be beyond all conjecture. The clue lies in the cryptic final clause of the interpretative act. That clause was intended to preserve the Manhattan Company, the present

counting bills." (Emphasis added.) N.Y. Sess. Laws 1892, ch. 687, § 19. In 1935 it was amended to except from its scope, and that of the Banking Law, inter alia, "the business of loaning money ... on bonds, notes or other evidences of indebtedness, secured by deeds of trust or mortgages upon real property or personal property situated in, upon or appurtenant thereto...." N.Y. Sess. Laws 1935, ch. 905.

44. N.Y. Sess. Laws 1804 , ch 110. 
Chase Manhattan Bank, which had been more or less unlawfully engaged in the business of banking since Aaron Burr and other equally enterprising men had induced the legislature of 1799 to grant them a charter as a water company, with very incidental authority to employ its "surplus capital . . . in the purchase of public or other stock, or in any other monied transactions or operations not inconsistent with the constitution and laws of this State or of the United States ...."45 The strong inference that the legislative friends of Aaron Burr and the Manhattan Company were no more anxious to publish their benevolence abroad in 1804 than in 1799, may explain the burial of the interpretative act and its peculiar closing clause.

Whatever the cause of its rapid descent into oblivion, and whether or not it was subsequently repealed by implication, ${ }^{46}$ the interpretative act throws a flood of light on the intention of the legislature of 1804 . That intent undoubtedly was to prevent unauthorized persons from conducting a general banking business, and possibly to keep them from carrying on any part of a general banking business, such as discounting, as an end in itself; but it was not to hinder the exercise of particular banking powers as an incident to the pursuit of some business other than banking. There is nothing in the language of the 1813 re-enactment or the 1818 supplement to indicate any alteration of this purpose. Eminent members of the contemporary commercial bar (and presumably their clients) so understood the purpose of the statute:

45. N.Y. Sess. Laws 1799 , ch. 84 . There is some dispute as to the extent, if any, to which the Manhattan Company ever diverted its time or funds to the water business, or any business other than banking. In modern times, the bank, dwelling affectionately on its past, likes to claim that it did operate a waterworks and, as proof, has from time to time exhibited sections of wooden waterpipe, of undoubted antiquity but dubious provenance. A painstaking and usually reliable historian of the city states that the Manhattan Company maintained a reservoir on Chambers Street until about 1885 and that as late as 1878 it had four customers, who "were regarded as something of a nuisance." Hariow, Ozd Bowery Days 127 (1931). On the other hand, in 1832 the Attorney General of the state, in the course of an abortive effort to oust the company of its charter, alleged without contradiction that "although a great number of citizens . . . had at all times since [1799] ... been willing and desirous to ... take ... water ... on such reasonable terms as should be demanded by the company, yet ... the company had not at any time since [1799] ... furnished ... any . . . quantity of pure and wholesome water for the use of all such citizens ...." People v. President \& Directors of the Manhattan Co., 9 Wend. 351, 357 (N.Y. Sup. Ct. of Judicature 1832). At any rate, it is certain that the pumping of water, in the literal sense, was never a preoccupation of the original directors or any of their successors.

46. As noted, the restraining act of 1804 was re-enacted in 1813 without change, as part of the revision of the laws in that year. Note 35 sitpra. The repealing act of the 1813 session provided that all acts theretofore passed which came within the "purview or operation" of any act passed during that session should be repealed. N.Y. Sess. Laws $1813, \mathrm{ch} .202$. In the course of the quo warranto proceedings against the Manhattan Company, mentioned in the preceding footnote, the court raised, but found it unnecessary to decide, the question whether the interpreting act fell within the "purview" of the restraining act of 1813, and was thereby repealed. People v. President \& Directors of the Manhattan Co., supra note 45 , at 391. 
[W] hat was the object of the restraining statutes? ... To prevent associations being formed wholly or principally for banking business-not to prevent other companies from doing any particular act which a bank does. ${ }^{47}$

As to the restraining act, in order to bring a company within its provisions, it must bank .... There must be a fund created and devoted to banking purposes.... If you depart from this you will be driven to call every act of discount or depasit an infraction. You would thus invade every counting house in the city, and the operations of every monied man in the community.... The act was levelled at private banks. ... We deny that here is any proof of our acting colourably as an insurance company. in order to interfere with the banking operations of other companies. ${ }^{48}$

Admittedly, these statements, which were not contradicted by opposing counsel or the court, were made before the Act of 1829 had added its specific injunction against a corporation's employing any of its property for the purpose of receiving deposits, making discounts or issuing circulating notes. But it seems intrinsically improbable that the legislature suddenly decided to deny to corporations, and only to corporations, the right to engage in transactions, as an incident to some business other than banking, which competing partnerships or individuals might properly continue to engage in while conducting such other business. It is much more likely that it simply intended to clear up uncertainty as to the applicability of the restraining act to corporations. ${ }^{40}$

47. D.B. Ogden, argutendo, in New-York Firemen Ins. Co. v. Ely, 2 Cow. 678, 684 (N.Y. Sup. Ct. 1824).

48. S. Jones, arguendo, id. at 696-97. To similar effect see Martin Van Buren, arguendo, in People v. Utica Ins. Co., 15 Johns. R. 358, 366-67 (N.Y. Sup. Ct. 1818). Compare Wigan v. Fowler, 1 Starkie 373 (K.B. 1816). An act of Parliament made it unlawful for any corporation, or association of more than six people, "to borrow, owe, or take up any sum or sums of money on their bills or notes payable at demand, or at any less time than six months from the borrowing thereof, during the continuance of such said privilege to [the Bank of England] ... .'" Ibid. It was argued that a demand note was illegal and void because issued by a seven-man commercial partnership. Lord Ellenborough, remarking that "the construction contended for would have the effect of crippling commerce exceedingly," held that "the protection meant to be given to the Bank was against Companies of Bankers, and . . . it was not the intention of the Legislature to prevent co-partners, who were not bankers, from ... drawing bills for the purpose of commerce." Id. at 374.

49. There seems to have been real doubt whether the Act of 1804 applied to corporations. Cf. People v. Utica Ins. Co., 15 Johns. R. 358, 366-67, 372, 377-78 (N.Y. Sup. Ct. 1818) (argument of counsel). The word "company" in those days might well have been thought to comprehend only on unincorporated association or a partnership; the legislature called a corporation a "body corporate," a "corporation" or an "incorporated company"-which latter phrase itself suggests that a "company" was not necessarily incorporated. The Act of 1818 extended its prohibition to a "body corporate" as well as individuals, but it barred only the keeping of an "office of deposit" for discounting and other banking purposes. It would not have prevented a corporation from engaging in all or any part of the banking business so long as it refrained from keeping an "office of deposit" for that purpase. N.Y. Sess. Laws 1818, ch. 236; see People v. Brewster, 4 Wend. 498, 500 (N.Y. Sup. Ct. 1830). 
Nor did the courts before the Miller case take the Draconian view that the restraining act voided each and every instrument discounted by an ordinary corporation; so far as the reports show, no case ever held void a note discounted by a corporate lender which was not engaged in some form of banking as an end in itself. Of the three leading cases decided under the Act of 1804, two invalidated the notes of an insurance company which, in an enterprising but unsuccessful effort to extend to the insurance business the principles which the Manhattan Company had so successfully applied to the water business, "used ... the liberties, privileges, and franchises of becoming proprietors of a bank ... . for the purpose of issuing notes, receiving deposits, making discounts, and transacting other business, which incorporated banks may do and transact by virtue of their acts of incorporation, by investing in the said bank and business the funds . . . which the business of insurance ... did not actively employ." The third case involved a note which a genuine insurance company discounted, apparently as an incident to its proper business. The court held the note void because usurious, but, for lack of evidence "that the funds of that Company were created, not for the purpose of insurance, but for the purpose of banking," the court rejected an argument that the discount violated the restraining act. ${ }^{51}$ Nor, under the act as amended and incorporated in the Revised Statutes, does there appear to be any case which condemned the discounting of a note by a corporation that was not singlemindedly engaged in some or all forms of banking. ${ }^{62}$

Concededly, the judicial test has not been simply whether the daily business of the discounting corporation was indistinguishable from that of the average bank. A number of courts, construing the restraining act in its various avatars, have found violations when the offender resembled a bank only in that it carried on the business of discounting. ${ }^{53}$ True, prior to 1956 respectable authority could have been adduced for the proposition that (despite the disjunctive

50. People v. Utica Ins. Co., supra note 49, at 364; Utica Ins. Co. v. Scott, 19 Johns. K. 1 (N.Y. Sup. Ct. 1821), rev'd, 8 Cow. 709 (N.Y. Ct. Err. 1826). The first case ousted the company of its charter; the second held void a note which it was found to have discounted, but was reversed on the grounds that the pleadings showed not a discount, but a loan, which the company's charter authorized it to make.

51. New-York Firemen Ins. Co. v. Ely, 2 Cow. 678, 702 (N.Y. Sup. Ct. 1824). Chief Justice Savage dissented, being of the opinion that the restraining act was violated by any exercise of a banking power by any person other than a bank. Id. at 711 .

52. Cf. New York State Loan \& Trust Co. v. Helmer, 77 N.Y. 64, 68 (1879) ("[P]laintiff kept a regular office for discount and deposit, carried on a regular banking business, discounted promissory notes and other commercial paper, bought and sold a large amount of exchange ... [received deposits and paid depositors' checks], and, in fact, did the ordinary business of a bank of discount and deposit.") ; Pratt v. Short, 79 N.Y. 437, 444 (1880).

53. E.g., Yorkville Business Protective Corp. v. Friedman, 144 Misc. 325, 258 N.Y. Supp. 689 (Sup. Ct. 1932) ; Proper Spirit Trading Corp. v. Schilowitz, 140 Misc. 171, 250 N.Y. Supp. 118 (App. T. 1931) ; Common Fin. Corp. v. Balsam, 133 Misc. 512, 231 N.Y. Supp. 656 (Sup. Ct. 1928) ; Gerard Commercial Corp. v. Pietrantonio, 133 Misc. 188, 231 N.Y. Supp. 493 (Sup. Ct. 1928) ; People v. Bartow, 6 Cow. 290 (N.Y. Sup. Ct. 1826). 
wording of the act) a corporation (such as a factoring company) whose principal business was in fact the exercise of some banking power, such as discounting, did not thereby necessarily employ its property in violation of that statute. ${ }^{54}$ Although the Miller case took the starch out of this argument, the crucial question of interpretation seems not so much whether the statute forbids making discounts "in a context unaccompanied by general banking operations"55 as whether it forbids making discounts in the context of some distinct business which is clearly not banking, like insurance or underwriting. The court of appeals virtually phrased the test in those terms in what was the landmark case before Miller. ${ }^{56}$ Unfortunately, having taken this broad and realistic view of the statute's purpose, the court proceeded to shrink the significance of its opinion, and facilitate the subsequent distinction of that case in Miller, by resting its decision on the somewhat technical ground that acquisition of an evidence of debt for less than par from someone other than the original maker is not a "discount" but that very different thing, "purchasing notes at less than their face value, apparently as a speculation." be regretted that the court of appeals did not in that case stand squarely on the ground that the discounter's principal business was one distinct from any form of banking, the fact remains that, so far as may be deduced from the sometimes cryptic opinions of the courts, no finding of a violation of the statute has involved a corporation having any business other than discounting which was substantial enough to be mentioned by the court. Pretty clearly, Discount Factors itself had no other business. ${ }^{58}$ Thus, nothing in the actual holding of

54. See Wolf v. Aero Factors Corp., 126 F. Supp. 872 (S.D.N.Y. 1954), aff'd, 221 F.2d 291 (2d Cir. 1955) ; Meserole Sec. Co. v. Cosman, 253 N.Y. 130, 142, 170 N.E. 519, 523 (1930) ; cf. Pennsylvania Factors Corp. v. S. Oldman, Inc., 272 App. Div. 1049, 74 N.Y.S.2d 670 (1947). The Wolf case involved a note secured by a chattel mortgage, and therefore, although interest had been deducted in advance, could be argued to be within the 1935 amendment to $\$ 18$ of the General Corporation Law, which provided that engaging in the business of loaning money on notes secured by mortgages of realty or "personal property situated in, upon or appurtenant thereto" should not be deemed a violation of the Banking Law. But the district court reasoned that a business corporation might "lend money ... without in any form conducting a banking business" and that "a factoring business is not a form of banking business." Wolf v. Aero Factors Corp., supra at 877.

55. See Kripke, supra note 12, at 1188.

56. "The distinction must always be borne in mind between the exercise in a commercial transaction of a power confided to a bank, and engaging in a form of banking." Meserole Sec. Co. v. Cosman, 253 N.Y. 130, 139, 170 N.E. 519, 522 (1930).

57. Id. at 142,170 N.E. at 523 .

58. Discount Factors, Inc. . . conceded upon the trial that it frequently entered into transactions of the present nature. It agreed that the normal pattern of its business was to make loans for which its charges were deducted in advance. ... We do not have any proof on the record ... . showing to what extent, if any, it carries on other activities by way of factoring or otherwise. ... We think it is a fair appraisal of the record on this appeal to say that Discount's business is the granting of financial assistance to merchants by lending money and taking back notes or buying their paper.

Miller v. Discount Factors, Inc., 285 App. Div. 772, 775-77, 141 N.Y.S.2d 140, 142, 144-45 (1955). 
the Miller case would bring within the condemnation of section 131 of the Banking Law a corporation which, as an incident to the transaction of its principal, nonbanking business, habitually discounts evidences of debt.59 This being so, a court so minded should have no difficulty-and should have had none before the 1958 amendment-in distinguishing the case of Discount Factors from that of an insurance company or underwriter.

The fact that the New York courts never squarely decided the applicability of the injunction against discounting to corporations which plainly were not trying to be banks is in large part attributable to the variety and ingenuity of the devices developed by a compassionate judiciary for the amelioration, not to say nullification, of the stringent statutory penalty. Discount Factors was, indeed, somewhat remarkable in devising a transaction which could not be fitted into any of the exceptions. As one measure of relief already noted, the statute was held to be inapplicable to an evidence of debt which had a "valid inception"-i.e., which was not discounted till it had left the hands of the maker. ${ }^{60}$ But even if a note were held to be void, all was not lost. The courts had reached back to Lord Mansfield's time to find a precedent which demonstrated that, by muscular construction, a statute ${ }^{61}$ voiding "Notes, Bills . . . or other Securities ... for any Money ... won by gaming . . . or lent . . . to any person or persons for gaming" need not interfere with the enforcement of such a debt, on the reasoning that the lender was "intitled to recover upon the original Consideration and Contract by the Justice and Equity of his Case, exclusive of any Assistance from the Bill of Exchange, and taking that to be a void Security."02 In effect, the New York judiciary left an unlawful discounter

59. On a number of occasions the inferior courts of New York, in determining whether an evidence of debt was void under $\S 131$, seem to have phrased the test in the language of $\S 18$ of the General Corporation Law-i.e., whether the corporation was "carrying on the business" of discounting, although the former statute denounces "making discounts." Possibly the courts tacitly reasoned that since the mere making of discounts, as distinct from carrying on the business of discounting, is a power not precluded by $\S 18$ of the General Corporation Law, it was "expressly authorized by the laws of this state" within the meaning of $\S 131$. See, e.g., Pennsylvania Factors Corp. v. S. Oldman, Inc., 272 App. Div. 1049, 74 N.Y.S.2d 670 (1947) (plaintiff, though it purchased a trade acceptance at a discount, was not "engaged in the banking business"); Yorkville Business Protective Corp. v. Friedman, 144 Misc. 325, 258 N.Y. Supp. 689 (Sup. Ct. 1932) (plaintiff "engaged in the business of making discounts"); Proper Spirit Trading Corp. v. Schilowitz, 140 Misc. 171, 173, 250 N.Y. Supp. 118, 121 (Sup. Ct. 1931) (plaintiff "employed its property, or at least a part of it, in the business of making discounts") ; Common Fin. Corp. v. Balsam, 133 Misc. 512, 231 N.Y. Supp. 656 (Sup. Ct. 1928) (plaintiff "had as a business discounted notes") ; Gerard Commercial Corp. v. Pietrantonio, 133 Misc. 188, 231 N.Y. Supp. 493 (Sup. Ct. 1928) (plaintiff "carrying on the business of discounting notes").

60. Meserole Sec. Co. v. Cosman, 253 N.Y. 130, 170 N.E. 519 (1930); Siebros Fin. Corp. v. 190 W. Fourth St. Realty Corp., 231 App. Div. 722, 245 N.Y. Supp. 902 (1930), aff'd mem., 256 N.Y. 586, 177 N.E. 151 (1931).

61. An Act for the better preventing of excessive and deceitful Gaming, 9 Anne, c. 14 (1710).

62. Robinson v. Bland, 2 Burr. 1077, 1078, 97 Eng. Rep. 717-18 (K.B. 1760). Lord Mansfield's reasoning was initially applied to the restraining act in Pratt $v$, Short, 79 N.Y. 437 (1880). 
with an action for money had and received. By a somewhat similar line of reasoning, the courts concluded that a mortgage or pledge securing a discounted note retained its vigor and enforceability despite a finding that the evidence of debt was void ${ }^{63}$-apparently even where the mortgagor was a mere guarantor or endorser, like Miller, so that no action for money had and received could have been brought against him. ${ }^{64}$ Courts which were not troubled by the fact that the restraining act voided not only notes but also "other securities for the payment of any money ..., or made or given to secure the payment of any money" which were discounted in violation of its provisions, found nothing but confirmation of their views in the 1935 amendment of section 18 of the General Corporation Law. This amended section modified the Banking Law by providing that "engaging in the business of loaning money in this state on bonds, notes or other evidences of indebtedness, secured by deeds of trust or mortgages upon real property or personal property situated in, upon or appurtenant thereto, . . . shall not be deemed or construed to violate any of the provisions of the banking law." ${ }^{65}$ The amendment referred only to loans, not discounts, and at first blush its language might seem somewhat difficult to apply to hypothecations of personalty unaccompanied by any mortgage of real estate. Undeterred by these considerations, the court that most recently considered the proviso concluded that it merely codified the previous case law. Thereupon the court enforced a chattel mortgage given to secure a series of notes discounted by a nonbanking corporation which "in the regular course of its business ... was the lender in many such transactions." 68 The court must have presumed that the qualifying phrase "situated in, upon or appurtenant thereto" was intended to exclude from the benefits of the exception mortgages upon personalty situated on the high seas or suspended in mid-air.

Prior to the Miller case, still other limitations on the scope of the restraining act had at least been adumbrated. There were judicial intimations, one from no less a source than Learned Hand, that the act applied only to the discounting of "commercial paper." Although the meaning of that phrase is far

63. E.g., Pratt v. Eaton, 79 N.Y. 449 (1880); Williams-Dexter Co. v. Dowland Realty Corp., 234 App. Div. 827, 253 N.Y. Supp. 987 (1931), aff'd mem., 259 N.Y. 581, 182 N.E. 189 (1932) (court of appeals held insufficient in law the defense to an action to enforce a mortgage that the note was void because discounted in violation of the restraining act).

64. E.g., Amherst Factors, Inc. v. Kochenburger, 4 App. Div. 2d 745, 164 N.Y.S.2d 815 (1957) ; Antipyros Co. v. Samuel Breiter \& Co., \& Misc. 2d 310, 165 X.Y.S.2d 976 (Sup. Ct. 1957), aff'd mem., 4 App. Div. 2d 941, 167 N.Y.S.2d 1002 (1957) ; County Industrial Corp. v. Francia, 5 Misc. 2d 602, 164 N.Y.S.2d 415 (Sup. Ct. 1957), aff'd mem., 4 App. Div. 2d 748, 165 N.Y.S.2d 699 (1957).

65. N.Y. Sess. Laws 1935, ch. 905.

66. New York Credit Men's Adjustment Bureau, Inc. v. Samuel Breiter \& Co., 253 F.2d 675, 676 (2d Cir. 1958).

67. See In re Worth Lighting Fixture Co., 292 Fed. 769, 773 (S.D.N.Y. 1923). See also Antipyros Co. v. Samuel Breiter \& Co., \& Misc. 2d 310, 312, 165 N.Y.S.2d 976, 978 (Sup. Ct. 1957), aff'd mem., 4 App. Div. 2d 941, 167 N.Y.S.2d 1002 (1957); Royal Diamond Co. v. Ostrin, 133 Misc. 555, 556, 232 N.Y. Supp. 223, 224 (Sup. Ct. 1928). 
from precise, in common parlance it certainly does not describe long-term bonds or debentures. In any event, neither the "commercial paper" cases nor any other case discussed in this Article dealt with the acquisition at less than par of bonds or debentures with long maturities, such as are commonly handled by insurance companies and underwriters. A similar construction seems to have been given by the Pennsylvania courts to a constitutional provision of that commonwealth which imposed special conditions on the creation of corporations with "banking or discounting privileges." 68 There, in a suit by an insurance company to enforce an assessment, one of the defenses was that the corporation "claims to exercise discounting privileges" in violation of the constitution and had therefore forfeited its franchise. But the court held that "discounting," as used in the constitutional provision, "is to be confined to dealing in promissory notes, bills of exchange or negotiable papers, for less than their face" and did not comprehend "the investment of money by ... insurance... or other corporations, in stocks, loans, bonds, mortgages and ground rents at less than their par value." 69 An early New York decision even suggested that the acquisition of such securities from the issuer at less than face value, with the intention of reselling them at a profit-as is the practice of underwriters, if not insurance companies-was not "discounting" at all. ${ }^{70}$ It must be conceded, however, that distinctions based on the length of maturity of the security discounted, or the intentions of the discounter (not to mention other, less plausible, circumventions of the statute), ${ }^{71}$ are not very easy to maintain in the face of the sweeping language of the Miller case.

Nevertheless, the efficacy of the principal palliatives-the concept that the obligor is always liable for money had and received and the allied notion that the validity and enforceability of a mortgage or other security are independent of the validity of the evidence of debt which it secures-seems not to have been weakened by the Miller case. ${ }^{72}$ That decision, naturally enough, sparked

68. PA. Const. art. I, § 25 (1838).

69. Lycoming Fire Ins. Co. v. Newcomb, 1 Leg. Chron. 9, 10-11 (Pa. C.P. 1872).

70. Talmage v. Pell, 7 N.Y. 328 (1852). A bank had purchased Ohio bonds from that state, had given the bank's certificates of deposit, payable at a future date, and had intended to resell the bonds at a profit. The court held the transaction beyond the powers of the bank, on the ground that it did not constitute discounting: "In a word, they purchased these bonds as they might have purchased a cargo of cotton, to send to market to be sold at the risk of the vendor for the highest price that could be obtained." Id. at 344.

71. There was a hopeful, though short-lived, effort to develop a doctrine that a stock corporation might lawfully discount the paper of its own stockholders; the practical effect of this rationale would be to add to the discounts, investigation fees, bonuses and other fees and charges a requirement that the unfortunate borrower purchase stock in the lender. Businessmen's Mortgage \& Credit Corp. v. Dobjinsky, 135 Misc. 628, 238 N.Y. Supp. 158 (N.Y.C. Munic. Ct. 1928) ; cf. Common Fin. Corp. v. Balsam, 133 Misc. 512, 231 N.Y. Supp. 656 (Sup. Ct. 1928). Contra, Proper Spirit Trading Corp. v. Schilowitz, 140 Misc. 171, 250 N.Y. Supp. 118 (Sup. Ct. 1931) ; Voluntary Ass'n, Inc. v. Goodman, 137 Misc. 388,244 N.Y. Supp. 328 (N.Y.C. Munic. Ct. 1930).

72. It is curious to note that in its original opinion in Miller, as reproduced in the unofficial report, the court of appeals adverted to cases holding void "notes (or other 
a series of attempts by hopeful signers and guarantors of discounted notes to utilize section 131 as a form of debtors' relief. An alert judiciary managed to distinguish each and every one of these situations from Miller. ${ }^{73}$

This battery of exceptions and distinctions, though a monument to judicial resourcefulness, and even capable of achieving substantial justice in many relatively small and simple transactions, is, from the standpoint of an insurance company, a good deal less than completely reassuring. Large institutional lenders, of course, often purchase debentures that are wholly unsecured by any hypothecation of property. The true security for such debentures lies in the protective covenants which they contain, perhaps in a guarantee by a parent or other corporation. But, as already suggested, if the debenture is void, it is hard to see how its covenants can be valid and enforceable. ${ }^{74}$ As the Miller case showed, the doctrine that the obligor of an illegally discounted note ought to be liable for money had and received is of no avail against an endorser of that note; and there is no pertinent distinction between an endorser and a guarantor-unless, considering that rationality has not been a significant element in the construction of the restraining act, it might be argued that a guarantee is a separate piece of paper, unaffected by the invalidation of the primary obligation. For that matter, it is far from clear that interest, either at the contract or legal rate, may be recovered from the obligor himself. ${ }^{75}$ Even if the

securities for the payment of moncy) discounted when a loan is made . ..." 135 N.E.2d at 37. (Emphasis added.) In the official report the italicized language has vanished. 1 N.Y. $2 \mathrm{~d}$ at 280,152 N.Y.S.2d at 277 . The motivation of this surreptitious amendment pretty clearly was a desire to scotch any inference that the decision overruled the cases that held enforceable an instrument securing a note discounted in violation of the statute. See New York Credit Men's Adjustment Bureau v. Samuel Breiter \& Co., 253 F.2d 675, 677-78 n.4 (2d Cir. 1958). But the intrinsic absurdity of that construction of the act is pointed up by the fact that the offending phrase is a nearly verbatim quotation of the statutory language.

73. New York Credit Men's Adjustment Bureau, Inc. v. Samuel Breiter \& Co., sipra note 72 (enforcing chattel mortgage to secure payment of money actually received by mortgagor) ; Amherst Factors, Inc. v. Kochenburger, 4 App. Div. 2d 745, 164 N.Y.S.2d 815 (1957) (holding both discounted notes and guarantor's mortgage valid); Antipyros Co. v. Samuel Breiter \& Co., 8 Misc. 2d 310, 165 N.Y.S.2d 976 (Sup. Ct. 1957), aff'd mem., 4 App. Div. 2d 941, 167 N.Y.S.2d 1002 (1957) (mortgage and guarantee enforced); County Industrial Corp. v. Francia, 5 Misc. 2d 602, 164 N.Y.S.2d 415 (Sup. Ct. 1957), aff'd mem., 4 App. Div. 2d 748, 165 N.Y.S.2d 699 (1957) (endorser's mortgage enforced); Mittman v. Kuo, 5 Misc. 2d 595, 160 N.Y.S.2d 743 (Sup. Ct. 1957) (mortgage enforced); Empire Factors Corp. v. 1305 Brook Ave., Inc., 135 N.Y.L.J. 10 (Sup. Ct. 1956) (mortgage enforced).

74. To the extent that the covenants are contained not in the debentures themselves but in an indenture or loan agreement under which they are issued and whose terms they incorporate by reference, it might be argued that the indenture is a "security" analogous to a mortgage and therefore endowed with independent life and enforceability. The argument is strained, but not much more so than the reasoning of the mortgage exception itself. Cf. Antipyros Co. v. Samuel Breiter \& Co., supra note 73; County Industrial Corp. v. Francia, supra note 73.

75. It has been suggested that a recovery of money had and received would bear interest at the legal rate "either from the date of the advance or the later date of demand." 
discounted evidence of debt is a bond secured by a mortgage, the lender, in practice, may not be much happier, for the realizable value of mortgaged property is frequently only a fraction of the amount of the debt which it secures. Bond purchasers rarely put their whole trust in the security behind their bonds; the protective covenants of bond indentures commonly approximate those of debenture indentures in both quantity and quality.

To make matters worse, it is arguable that the 1958 amendment to section 131 effectively knocked the props from under the rationale on which the courts laboriously erected the right of the unlawful discounter to recover money had and received and to enforce a mortgage. The heart of that reasoning was the hoary principle that where a statute prescribes a pound of flesh as penalty, the courts will be astute to see that no drop of blood is shed:

In view of the special language of the restraining act, and the specification of the consequences which should follow the unlawful discount of commercial paper, there is great force in the suggestion that the Legislature regarded the particular penalty imposed ... as a sufficient protection against corporations . . u unlawfully engaging in the business of discounting paper, and that it was not intended that they should also forfeit all claim to money loaned or advanced upon the prohibited security. ${ }^{76}$

But the 1958 amendment excised the specific penalty for illegal discounting. The net effect is that the discounting of an evidence of debt by a nonbanking corporation prior to April 25, 1958 (the date of the prospective, healing amendment), is-in view of the deliberate deletion of the retroactive provision of the amendment-probably still illegal, albeit no definite penalty is placed upon the illegality. In such a case it can-and probably will-be argued that the courts must fall back upon "the general rule of law, that no right of action can spring out of an illegal contract," a rule which "applies as well to contracts malum prohibitum, as to contracts malum in se."77

And that is exactly what the court of appeals held a century ago in what seems to be the only case involving an attempt to enforce a contract which

See Kupfer, supra note 16, at 36 n.12. But the cases throw little light on the question, or on the allied question whether a discounter is entitled to recover the face amount of the discounted note or only the amount actually received by the borrower. In WilliamsDexter Co. v. Dowland Realty Corp., 234 App. Div. 827, 253 N.Y. Supp. 987 (1931), aff'd mem., 259 N.Y. 581, 182 N.E. 189 (1932), the court, enforcing a mortgage of real property which secured a note alleged to have been illegally discounted, rejected a claim that the "bonus" taken by the lender, together with the interest paid on such bonus, should be disallowed in the computation of the amount due the mortgagee. But in Pratt v. Short, 79 N.Y. 437, 449 (1880), which did not involve a mortgage, the court required only that the defendants "restore the money which they received," which seems to imply that they were not obligated for the face amount of the discounted note.

76. Pratt v. Short, supra note 75, at 448-49. To similar effect, see, e.g., Ernst v. Terminal Clearing House Ass'n, 86 Misc. 295, 297, 149 N.Y. Supp. 181, 183 (Sup. Ct. 1914), aff'd mem., 167 App. Div. 902, 151 N.Y. Supp. 1114 (1915).

77. See Pratt v. Short, 79 N.Y. 437, 445 (1880). 
violated the restraining act but which was not an evidence of debt discounted in violation thereof and hence was subject to no prescribed penalty. ${ }^{78}$ In that case, the plaintiff, an unincorporated association carrying on a banking business in Montreal, entered into a contract under which one Brisbane, a resident of New York, was to take plaintiff's bank notes and use them for the discounting of notes in New York, the profits to be equally divided. Brisbane gave the plaintiff his bond for the repayment of the sums advanced to him, and his father, to secure the bond, gave the plaintiff a mortgage of real estate. Upon Brisbane's default, and the plaintiff's attempt to enforce the mortgage, the court held the contract illegal and void, because its execution necessarily involved a violation of the restraining act, ${ }^{79}$ and therefore simply refused to "lend its aid to a man who founds his action upon an illegal contract." 80 It may be assumed-though the Miller case does not encourage the making of optimistic assumptions as to the court of appeals' attitude when dealing with section 131 of the Banking Law-that the courts will not be noticeably eager to resurrect the Brisbane case and apply it to evidences of debt unlawfully discounted prior to April of 1958. Nevertheless, the next court to face the question must either ignore, distinguish or overrule the Brisbane case if it wants to enforce a debt evidenced by an illegally discounted note, debenture or bond. None of these processes is likely to be particularly simple. It might be easier, as it would certainly be more straightforward, squarely to decide the proper scope of that statute in the light of its long and troubled history.

\section{SUMMARY}

In a nutshell, the 1958 amendments of the Banking and General Corporation Laws did not, in all probability, lay the ghost of the Miller case. However unintentionally, those amendments may in fact have created totally new and pestiferous problems. No doubt the statute could be amended again-and ought to be. But any such return to the problem should involve considerably broader, more painstaking and more painful thinking than the New York legislature has shown any disposition to devote to it. Reconsideration should, for example, include a real study of the exceedingly complex problem of regulating such lenders as Discount Factors. ${ }^{81}$ The kind of regulation represented by the Miller case resembles brain surgery with a cleaver. No less dangerous, on the other hand, is the present amendment's failure to regulate a class of lenders, however necessary, the exigence of whose clients is a standing temptation to

78. DeWitt v. Brisbane, 16 N.Y. 508 (1858).

79. The violation lay not in the discounting of notes but in the keeping of an office for the purpose of issuing evidences of debt-i.e., the Canadian banknotes-to be put into circulation as money. At that time it was not illegal for either an individual or an unincorporated association to engage in discounting.

80. DeWitt v. Brisbane, 16 N.Y. 508, 512 (1858).

81. See Miller v. Discount Factors, Inc., 285 App. Div. 772, 778, 141 N.Y.S.2d 140, 146 (1955). 
predacity. But the legislature, having solved the immediate problem to its own satisfaction and hushed the cries of the insurance companies, is not likely to embark soon on a project which is neither easy nor apt to return quick political dividends. If there is no amendment, then sooner or later, most probably in the context of reorganization or bankruptcy of a corporation some of whose outstanding securities were discounted in New York prior to April 25, 1958, by a nonbanking corporation, the problems herein discussed are going to be raised. And when that time comes, antiquarian research into the history of New York's restraining act will be necessary and, perhaps, profitable. 


\section{THE YALE "LAW JOURNAL}

Matthew T. Adams

David AlBenda

Alan Appelbaum

ROBERT L. BARD

ARTHUR J. BERK

Normian A. Bikales

Benjamin W. Boley

Riceard A. Brady

Peter D. Caldwell

JaMES M. EDWARDS

ELIEZER EREII

David R. Evans

J. EDWARd FowLer

THOMAS N. FroHOCK

David GoldBerg

\section{SYDNEY M. CONE, III \\ Editor-in-Chief}

\author{
ROBERT J. ENGELMAN \\ Article and Book \\ Review Editor
}

\section{MITCHer J. Ezer \\ Managing Editor}

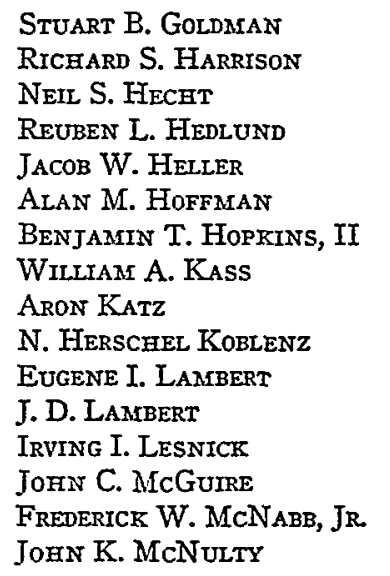

Stuart B. Goldaran

RICHARD S. HARRISON

NeIL S. HECHT

REUBEN L. HEDLUND

JACOB W. HELLER

ALAN M. HoFFMA

BENJAMIN T. HopkINS, II

WiLIIAM A. Kass

Aron Katz

KOBLEN

UGENE I. LAMIBERT

IRVING I. LESNICK
Jerold H. IsRaed
Alan L. Wurtzez
Note Editors

\author{
Stephen MANN \\ Bruce Montgomery \\ JerRold L. MORGULAS \\ SAMUEL MYers \\ J. Alexander ONDERDONK \\ Alan D. Perelner \\ Charles J. Prentiss \\ Herpert Schretber \\ Barry StDman \\ Richard Lauder Sutton \\ Colin C. TaIt \\ Gilbert Paul Verbit \\ Herbert S. WANDER \\ Donald P. Wefer \\ T. Cecil Wray, Jr.
}

Marie McMahon
Business Secretary
David BerLiner

Business Manager

\section{CONTRIBUTORS TO THIS ISSUE}

Herbert Brownell, JR. A.B. 1924, LL.D., University of Nebraska; LL.B. 1927, Yale University. Attorney General of the United States, 1953-1957. Past Chairman, Republican National Committee. Counsel, firm of Lord, Day \& Lord, New York City.

W. L. MoRIson. B.A. 1940, LL.B. 1944, University of Sydney; D. Phil. 1951, University of Oxford. Member of the Staff of the Department of External Affairs, Australia, 1944-1946. Senior Fellow and Visiting Lecturer in Law 1957-1958, Yale Law School. Associate Professor of Common Law, University of Sydney.

C. Ropert Morris, Jr. B.A. 1948, St. John's College; LL.B. 1951, Yale University. Member of the Texas Bar. Associate Professor of Law, Rutgers University School of Law.

Joseph W. Bishor, Jr. B.A. 1936, Dartmouth College; LL.B. 1940, Harvard University. Deputy General Counsel of the Army, 1952-1953. Member of the District of Columbia and New York Bars. Associate Professor of Law, Yale Law School. 